Studies in African Linguisticss

Volume 26, Number 2, Fall 1997

\title{
TWO KINDS OF MORAIC NASAL IN CIYAO*
}

\author{
Larry M. Hyman \\ University of California, Berkeley \\ and \\ Armindo S. A. Ngunga \\ University of California, Berkeley \\ Eduardo Mondlane University
}

\begin{abstract}
A problematic issue in a number of Bantu languages concerns the phonological analysis of "preconsonantal nasality", i.e., the question of whether NC entities should be analyzed as single prenasalized consonants or as sequences of nasal + (homorganic) consonant. In this paper, the authors examine two kinds of moraic nasal-one syllabic, one not-in Ciyao, a Bantu language spoken in East Africa. They further demonstrate that there is a third type of preconsonantal nasality in Ciyao which is neither moraic nor syllabic.
\end{abstract}

\section{Introduction}

Among the few problematic issues surrounding the syllabification of consonants in Bantu languages is the proper interpretation of "preconsonantal nasality": For each relevant language of the family, one must first ask whether the sequencing of [+nasal] [-nasal] in forms such as Proto-Bantu *ba-ntu 'people' is properly viewed as a consonant cluster or as a single prenasalized consonant. Noting that

* Research on Ciyao has been conducted in the context of the Comparative Bantu On-Line Dictionary (CBOLD) project, supported in part by National Science Foundation Grants \#SBR9319415 and \#SBR96-16330. Earlier versions of this paper were given at U.C. Santa Cruz, Université Lumière Lyon2, Université d'Aix-en-Provence, and the University of Edinburgh. We would like to thank the participants at these presentations as well as Robert Botne and two anonymous reviewers for helpful comments on the paper. 
preconsonantality frequently lengthens a preceding vowel and may also count as a tone-bearing unit, a number of recent publications have provided analyses that either start with or assign a mora to NC sequences [Bickmore 1989, 1991; Downing 1991; Hubbard 1995, 1996; Hyman 1992; Maddieson 1993; Odden 1991]. Not addressed in most of these accounts is the fact that quite a number of Bantu languages have more than one type of preconsonantal nasality (but see Odden [1996]). One such language is Ciyao, classified as P.21 by Guthrie [19671971] and spoken in Mozambique, Tanzania, and Malawi. The variant of Ciyao described in this study is that spoken in Chicónóno (Mozambique), of which the second author is a native speaker.

As indicated in (1), in this language there are three kinds of preconsonantal nasality. These three types of nasality result in two distinct two-way oppositions. Morpheme-internally - specifically, in lexical roots- $\mathrm{NC}$ contrasts with ${ }^{\mathrm{N}} \mathrm{C}$. That is, there exists a contrast in moraicity only, both nasal types being non-syllabic. A syllabic contrast in nasals is found across morpheme boundaries with certain $\mathrm{N}$ final prefixes plus $\mathrm{C}$-initial roots, i.e., a contrast between syllabic N'C and nonsyllabic NC.

(1) Three types of preconsonantal nasality in Ciyao:
a. Moraic but not syllabic
(symbolized as NC)
b. Moraic and syllabic
(symbolized as N'C)
c. Non-moraic and non-syllabic
(symbolized as $\mathrm{NC}$ )

As documented in Kadima [1969] and Bell [1972], Ciyao is not alone in having two kinds of moraic nasals (see also Givón [1974] and Herbert [1986]). The presence of a three-way distinction, including non-moraic preconsonantal nasality, is less frequent, in fact unreported, as far as we know. The purpose of the present study is to provide an account of the moraic representation and derivation of all three types of preconsonantal nasality in Ciyao. As we shall see, the presence of the syllabic nasal $\left(\mathrm{N}^{\prime}\right)$ crucially interacts with representations that have been proposed for the moraic nasal $(\mathrm{N})$. The paper is organized as follows: We begin in $\S 1$ with a presentation of the properties of the moraic nasal, primarily its lengthening effect on the preceding vowel and its interactions with the following consonant. In $\$ 2$ we describe the corresponding properties of the syllabic nasal, showing that it has neither of the effects of the moraic nasal. We then present our analysis of both types of moraic nasals in §3. In this last section we draw evidence from the non-moraic (and non-syllabic) nasal $(\mathrm{N})$ to show that the distribution of the syllabic nasal is allomorphically conditioned. 


\section{The Moraic Nasal}

As mentioned, Ciyao has three types of preconsonantal nasality. The first which we shall consider is reconstructed for Proto-Bantu and corresponds to the nasal discussed in recent moraic accounts [Bickmore 1989; Downing 1991; Hubbard 1995, 1996; Hyman 1992; Maddieson 1993]. In Ciyao, this nasal, which we refer to as the "moraic nasal", has an effect both on the preceding vowel as well as on the following consonant. First, as seen in (2), the sequence moraic nasal + consonant conditions a lengthening of the preceding vowel (cf. Hubbard [1994] and Ngunga [1995] for phonetic details). The examples in (2) illustrate the moraic nasal as it occurs intramorphemically (i.e., here within a verb root). ${ }^{1}$ We provide one example of each of the four NC sequences that exist in the language (the $\mathrm{C}$ being necessarily voiced). As is customary in Bantu studies, length is indicated by doubling the vowel in question. 2

(2) Vowel lengthening before moraic $\mathrm{N}+\mathrm{C}$

a. [mb] : ku-gúmb-á $\rightarrow$ ku.gúú. mb-á 'to mould'

b. [nd] : ku-ténd-á $\rightarrow$ ku.téé.nd-á 'to do'

c. [nj] : ku-sánj-á $\rightarrow$ ku.sáá.nj-á 'to sharpen (tool)'

d. [ng] : ku-cíng-á $\rightarrow$ ku.cîing-á 'to herd'

This lengthening process, which is informally captured by the linear rule in (3), has been the subject of several non-linear studies. The first of these, Clements' [1986] analysis of Luganda, provides an account utilizing the CV framework of Clements and Keyser [1983]. Subsequent studies have substituted X's for the C's and V's of the skeletal tier-or have used moras.

$$
\mathrm{V} \rightarrow \mathrm{V}: / \ldots \mathrm{NC}
$$

1 In (2), $k u$ - is the class 15 prefix used to form infinitives, while the -á is the inflectional final vowel (FV) morpheme which is required on most verb forms. In subsequent examples, the FV will not be separated from the rest of the verb stem. Throughout the study, transcriptions follow standard IPA except that "c" and "j" stand for alveopalatal affricates.

2 One reviewer suggests that the vowel length in (2) may be analyzed as underlying, particularly as the language does have a limited number of forms where a short vowel precedes the NC (see \$3.3). The major point we wish to make is that morpheme-internal preconsonantal nasality is affiliated with preceding vowel length in the general case. Thus, among the 2,591 cases of a morphemeinternal VNC sequence in the second author's lexical database of Ciyao, only $213(8.2 \%)$ involve a short vowel. By contrast, of the 9,681 cases of morpheme-internal vC sequences (where $C \neq N C$ ), $7,278(75.2 \%)$ are short vowels. Given these statistics, even if we were to set up an underlying intramorphemic contrast between / VNC/ and /VVNC/, we would have to account for the differential distribution of these sequences versus / VC/ and /VVC/. By identifying the mora that provides length on the preceding vowel with the nasal, we are able to relate the majority of VVNC cases to the moraic nasal prefixes discussed in this section. 
Translating Clements' analysis into a moraic framework, a straightforward account would be as summarized in (4). In the input in (4a), the moraic nasal is prelinked to a mora, which is substituted for the V slot that Clements [1986] had proposed. The output in (4b) shows two differences from the input in (4a): First, the nasal has left its mora to join the following one (thereby creating a prenasalized consonant). Second, by a process of compensatory lengthening (CL), the vowel has taken over the mora of the nasal and become long.

(4) Pre- and post-compensatory lengthening (CL) representations of -ténd-á 'do'
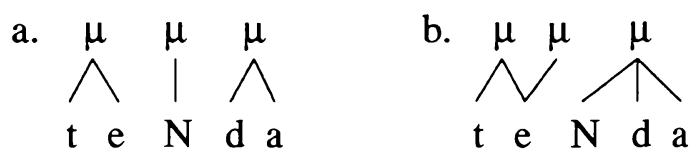

Assuming, as implied, a derivational approach, there are two logical interpretations of the two-part change in (4). These are formalized in (5). Borrowing a concept from historical linguistics, in $(5 \mathrm{a})$ we have what can be called a "drag chain" effect. In this interpretation, the process is triggered by the change of status of the nasal. As shown, by a process of spreading + delinking, the nasal shifts from its mora onto the following mora. Subsequently, the preceding vowel spreads ("is dragged") onto the freed up mora. In the interpretation represented in (5b), we have a "push chain" effect, which is again triggered by a spreading + delinking process: The vowel first spreads to the right onto the following mora, from which the nasal delinks. This is followed by "pushing" the nasal to relink to the following mora.

(5) “Drag" vs. "push" interpretations of the CL trigger

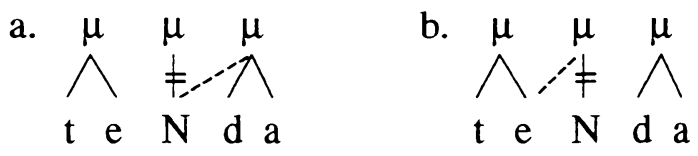

Having considered this phenomenon across several Bantu languages, we have determined that the choice between the two interpretations in (5) is a subtle one, at best. ${ }^{3}$ As we shall see in $\S 4$, the problem disappears when we propose that the nasal is not actually prelinked to its mora.

3 The reader may wish to reconsider in this context the interpretation of other cases of CL in Luganda also treated by Clements [1986]. Consider, for example, the change of $/ \mathbf{k u a} /$ to [ $\mathbf{k}^{\mathrm{w}} \mathrm{aa}$ ], which occurs in Luganda, Ciyao, and many other Bantu languages. As pointed out to us by Nick Clements (personal communication), and as seen in (a) and (b) on the next page, there are two possible interpretations of this change within Clements' CV framework. In (a), Clements' analysis, the $/ \mathrm{u}$ / first shifts from its $\mathrm{V}$ to the preceding $\mathrm{C}$, thereby creating a labialized consonant $\left[\mathrm{k}^{\mathrm{w}}\right]$. The continued on next page ... 
Besides its lengthening effect on the preceding vowel, the moraic nasal conditions major interactions with the following consonant. As mentioned in connection with the examples in (2), the only surface manifestations of NC derived from the moraic nasal are [mb, nd, nj, $\mathrm{gg}]$, i.e., the post-nasal consonant must be voiced. In order to see why this is the case, we must enlarge our scope to consider the full distribution of the moraic nasal.

(6) Distribution of the moraic nasal

a. Morpheme-internally, i.e., in roots : see (2)

b. 1st person singular object prefix $-\mathrm{N}-\quad$ : see (7)

c. 1 st person singular subject prefix $-\mathrm{N}-\quad$ : see (8)

d. Class $9 / 10$ noun prefix $\mathrm{N}-\quad$ : see (9)

As indicated in (6), the moraic nasal occurs in four contexts in Ciyao. We have already seen examples of morpheme-internal NC in (2). Now consider the examples in (7) involving the 1st person singular object prefix - $\mathrm{N}$-, which occurs between the infinitive prefix $\mathrm{ku}$ - and the verb root. As seen in all the examples, the vowel of $k u$ - lengthens as expected and, except for (7d), the nasal is realized homorganic to the following consonant.

(7) Lengthening of $k u$ - before $-\mathrm{N}$ - ' 1 st person singular object prefix' (= homorganic to following $\mathrm{C}$ )

a. When the following consonant is voiceless, it becomes [+voice]

$\begin{array}{lll}\text { ku-N-péleka } & \rightarrow \text { kuu-m-béleka 'to send me' } \\ \text { ku-N-túma } & \rightarrow \text { kuu-n-dúma 'to order me' } \\ \text { ku-N-cápila } & \rightarrow \text { kuu-n-jápila 'to wash for me' } \\ \text { ku-N-kwéela } & \rightarrow \text { kuu- } \eta \text {-gwéela 'to climb on me' }\end{array}$

following /a/ spreads ("is dragged") onto the preceding available V. In (b) the process begins when the vowel /a/ spreads onto the preceding $\mathrm{V}$ slot of / $\mathrm{u} /$, which then delinks (and is "pushed" onto the preceding $\mathrm{C}$ slot).

(a) $\begin{array}{lll}\mathrm{C} & \mathrm{V} & \mathrm{V} \\ \mathrm{W} & \neq & 1 \\ \mathrm{k} & \mathrm{u} & \mathrm{a}\end{array}$

(b) $\begin{array}{lll}\mathrm{C} & \mathrm{V} & \mathrm{V} \\ \mathrm{l} & \neq & -\mathrm{l} \\ \mathrm{k} & \mathrm{u} & \mathrm{a}\end{array}$

(c)

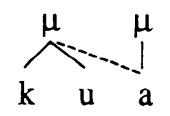

Again the choice between the two interpretations is a subtle one. Note, however, that within the moraic framework of Hyman [1985] in (c) there is only one interpretation: the vowel /a/ spreads onto the preceding $/ \mathrm{ku} / \mathrm{mora}$, thereby creating the required length. Within this framework, the desyllabification of $/ \mathrm{u} / \mathrm{to}[\mathrm{w}]$ is a direct consequence of $/ \mathrm{u} /$ being less sonorous than $/ \mathrm{a} /$. 
b. When the following consonant is voiced, it deletes

$\begin{array}{llll}\text { ku-N-búúcila } & \rightarrow & \text { kuu-múúcila } & \text { 'to be angry with me' } \\ \text { ku-N-vácíla } & \rightarrow & \text { kuu-mácíla } & \text { 'to build for me' } \\ \text { ku-N-lápa } & \rightarrow & \text { kuu-nápa } & \text { 'to admire me' } \\ \text { ku-N-jíima } & \rightarrow & \text { kuu-níima } & \text { 'to begrudge me' } \\ \text { ku-N-góneka } & \rightarrow & \text { kuu-nóneka } & \text { 'to make me sleep' } \\ \text { ku-N-mála } & \rightarrow & \text { kuu-mála } & \text { 'to finish me' } \\ \text { ku-N-néma } & \rightarrow & \text { kuu-néma } & \text { 'for me to do incorrectly' } \\ \text { ku-N-nála } & \rightarrow & \text { kuu-nála } & \text { 'to cut me into small pieces' } \\ \text { ku-N-náándila } & \rightarrow & \text { kuu-náándila } & \text { 'to play around with me' }\end{array}$

c. An exception to (7b) is $/ \mathrm{d} /$, which does not delete

$\begin{array}{lll}\text { ku-N-dipa } & \rightarrow \text { kuu-n-dípa 'to pay me' } \\ \text { ku-N-délela } & \rightarrow \text { kuu-n-délela 'to understimate me' }\end{array}$

d. The moraic nasal deletes when followed by /s/

ku-N-sóosa $\rightarrow$ kuu-sóosa 'to look for me'

Considering each set of forms separately, in (7a) the moraic nasal voices a following voiceless /p, t, c, k/. In (7b), on the other hand, an input voiced consonant deletes after the moraic nasal. 4 Each of these two generalizations has one exception. First, in (7c) we see that [d] does not delete after the moraic nasal. 5 Second, in (7d) we see that /s/, the only voiceless fricative in the language, does not voice to become [z]. Instead, the common process of nasal effacement takes place and the moraic nasal is lost (leaving behind its CL effect on the preceding vowel).

In (8) we see exactly the same changes as noted in (7), but this time involving the 1 st person singular subject prefix $\mathrm{N}$-. In all examples, the final vowel of the preposed temporal adverb leeló 'today' is lengthened, showing that the CL process conditioned by the moraic nasal also applies across words. In addition, in (8a) underlying voiceless $/ \mathrm{p}, \mathrm{t}, \mathrm{c}, \mathrm{k} /$ are all voiced after the moraic nasal, whereas in (8b) underlying oral voiced consonants are all deleted. Examples in (8c) show

4 Kenstowicz and Kisseberth [1977:157] cite identical facts to those in (7a) and (7b) in the very closely related language (ci-)Mwera studied by Harries [1950] as an example of counter-feeding rule ordering: The voiced consonants must delete prior to the voicing of voiceless consonants. Otherwise one will obtain a derivation of $\mathrm{mp} \rightarrow \mathrm{mb} \rightarrow \mathrm{m}$, which is incorrect. Of course, a simultaneous rule application (or "direct mapping" as Kenstowicz and Kisseberth refer to it) would also work.

5 While there is an underlying /d/, which occurs in a restricted number of roots, most occurrences of non-prenasalized [d] result from a rule that converts $/$ / to [d] before $/ \mathrm{i} / \mathrm{:}$ ku-mílá [mílá] 'to swallow' vs. ku-míl-il-a [mídila] 'to swallow for'. Whether deriving from $/ 1 /$ or $/ d /$, [d] never deletes after the moraic nasal. 
the non-deletion of [d], while (8d) shows the deletion of the moraic nasal before $/ \mathrm{s} /$.

(8) Lengthening of final vowel of preceding word before N-

'1st person singular subject prefix'
a. leelóó m-beléece 'today I sent'
leelóó n-dumíle 'today I ordered'
leelóó $n$-japíile 'today I washed for (s.o.)'
leelóó $\mathrm{n}$-gweesíle 'today I climbed'
b. leelóó muucíle 'today I was angry'
leeló macíile 'today I built for'
leelóó napíle 'today I admired'
leelóó jiimíle 'today I begrudged'
leelóó nonéece 'today I made (s.o.) sleep'
leelóó masíle 'today I finished'
leelóó nemíle 'today I did (sth.) incorrectly'
leeló nasíle 'today I cut into small pieces'
leelóó naandíile 'today I played around with (sth.)'
$\begin{array}{lll}\text { c. leelóó } & n \text {-dipíle } & \text { 'today I paid' } \\ \text { leelóó } & n \text {-deléele } & \text { 'today I underestimated' }\end{array}$
d. leelóó soosíle 'today I looked for'

Finally, the fourth context where a moraic nasal is found concerns the noun class prefix $\mathrm{N}$ - used both in singular class 9 and in its corresponding plural class 10. This prefix is illustrated in (9). Again, all examples show vowel lengthening before the moraic nasal, in this case, lengthening of the FV of the verb ku-lék-á 'to leave'. The examples in (9a) involve nouns which have a voiced consonant following the nasal prefix. The examples in $(9 \mathrm{~b})$ begin with a nasal consonant, while the example in (9c) begins with an /s/ which has conditioned the deletion of the preceding moraic nasal prefix. 6

6 We have found a number of class $9 / 10$ nouns lacking a surface (or underlying) nasal prefix. In these cases the preceding vowel is not lengthened, e.g., ku-léká kábuduula 'to leave shorts', $k u$-éká tóondé 'to leave a billy-goat'. 
(9) Lengthening of final vowel of preceding word caused by $9 / 10 \mathrm{~N}$ - prefix
a. ku-lékáá m-búsí 'to leave a goat'
ku-lékáá n-dinú 'to leave a porcupine'
ku-lékáá $n$-jatí 'to leave a buffalo'
ku-lékáá $\eta$-goosa 'to leave a sheep'
b. ku-lékáá meémbe 'to leave a fly'
ku-lékáá nalúmé 'to leave a young elephant'
ku-lékáá nama 'to leave an animal'
ku-lékáá noombe 'to leave a cow'
c. ku-lékáá sóomba 'to leave a fish'

It is clear from the lengthening of a preceding vowel that the nasal of these prefixes is moraic. Evidence that the moraic nasal is underlyingly $n$-is presented in (10). In these forms, the 1 st person singular subject prefix is directly followed by a vowel, here the /-á-/ Past2 ("before today") tense marker.

(10) '1st person singular subject prefix' is underlyingly moraic $/ \mathrm{n}-/$
a. diisó $n$-áá-péleece 'yesterday I sent'
diisó n-áa-túmilé 'yesterday I ordered'
diisó $\quad n$-áá-cápiíle 'yesterday I washed for (s.o.)'
diisó $\quad n$-áá-kweesilé 'yesterday I climbed'
b. diisó n-áá-búúcilé 'yesterday I was angry'
diisó n-áá-vácíle 'yesterday I built for'
diisó $n$-áá-lápilé 'yesterday I admired'
diisó $\quad n$-áá-jíimilé 'yesterday I begrudged'
diisó $\quad n$-áá-góneéce 'yesterday I made (s.o.) sleep'
diisó $\quad n$-áá-másilé 'yesterday I finished'
diisó n-áá-némilé 'yesterday I did (sth.) incorrectly'
diisó n-áá-násilé 'yesterday I cut into small pieces'
diisó n-áá-ᄁáándiíle 'yesterday I played around with (sth.)'
$\begin{array}{lll}\text { c. diisó } & n \text {-áá-dipilé } & \text { 'yesterday I paid' } \\ \text { diisó } & n \text {-áá-déleéle } & \text { 'yesterday I underestimated' }\end{array}$
d. diisó n-áá-sóósilé 'yesterday I looked for'

There are three observations of note. First, the nasal is realized phonetically as [n-]. We are thus justified in setting up the moraic nasal either as $/ \mathrm{n}-/$ or as $/ \mathrm{N}-/$ with the alveolar realization in (10) being the result of a default spell-out as alveolar (i.e., in the absence of homorganic nasal assimilation). The second 
observation is that the final vowel of /diisó/ 'yesterday' does not lengthen. This is explained by the third observation: the lengthening of the tense prefix -á-after the moraic nasal. As seen in (11), when the moraic nasal is followed by a vowel, the vowel spreads to the left to create a CV mora. ${ }^{7}$ As a result, the nasal does not delink from its mora, which in turn is not available to produce the CL of the preceding vowel seen elsewhere. The final vowel of diisó is thus short in all of the examples in (10). With this last bit of evidence, we are thus confident of the motivation of both the $/ n-/$ and the mora affiliated with it.

\section{(11) $/ \mathrm{n}-/$ passes its moricity onto a following vowel: (hence, not onto a preceding vowel)}

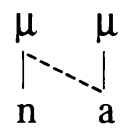

Analyses of moraic nasals vary from having the nasal prelinked to an underlying mora (or equivalent) (cf. Clements [1986] and Hyman [1992]), to not having any mora underlying at all (see especially Downing [1991]). Our examination of the properties of the moraic nasal in this section has assumed a prelinked mora.8 In $\S 4$ we shall modify this assumption and propose a third, intermediate position, namely, one in which the mora is underlying but the nasal is not prelinked to it. One reason is that we wish to reserve the representation of a nasal prelinked to a mora for the second moraic nasal in the language, which has very different properties from the nasal prefixes we have just examined. This second moraic nasal, which we refer to as the "syllabic nasal", is treated in the next section.

\section{The Syllabic Nasal}

In this section we present the properties of the second type of nasal, the syllabic nasal, whose properties should be compared to those seen in $\$ 1$ concerning the moraic nasal. As we shall discuss in §3.3, this syllabic nasal derives from ProtoBantu *mu- and even alternates with $m u$ - and $m w$ - in Ciyao. Since there are no

7 We see the leftward spreading process in (11) as identical to that in (c) in fn. 3 . We should note, however, that an analysis that recognized the tense prefix as long, i.e., as - $a a-$, which would only slightly complicate the syllabic and tonal phonology, might be argued as an alternative.

8 Somewhat problematic would be for the nasal to acquire a mora by "weight by position" [Hayes 1989] or other means, to which it links and then delinks. Such an approach has been taken for other Bantu languages (e.g., Bickmore [1991], Downing [1991]). As we have seen, the mora must be underlying because of its realization when a vowel follows: the following vowel lengthens, while the preceding vowel does not. An equally compelling reason is found in Luganda, where the "moraic nasal" is realized as a geminate when followed by a vowel. Thus, compare y-a-gúlà 'he bought' vs. nn-a-gúlà 'I bought' (see Hyman and Katamba [1997] and references cited therein). 
morpheme-internal syllabic nasals in the language, we begin by considering the 2nd/3rd person singular object prefix in (12).

(12) No lengthening before $-\mathrm{N}$ '- '2nd/3rd person singular object prefix'
a. $k u-N^{\prime}$-péléka
$\rightarrow$ ku-m'-péleka
'to send you/him'
ku-N'-túmá

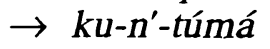
'to order you/him'
ku-N'-cápíla $\rightarrow$ ku- $n^{\prime}$-cápila
'to wash for you/him'
ku-N'-kwééla
$\rightarrow k u-\eta^{\prime}-k w e ́ e l a$
'to climb on you/him'
b. ku-N'-búúcila
ku-N'-vácíla
$\rightarrow$ ku-m'-búúcila
'to be angry with you/him'
ku-N'-lápá
$\rightarrow$ ku-m'-bácíla
'to build for you/him'
ku-N'-jímá
$\rightarrow k u-n^{\prime}-n a ́ p a ́$
ku-N'-gónéka

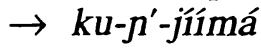
'to admire you/him'
$\rightarrow$ ku- $\eta^{\prime}$-gónéka
'to begrudge you/him'
$k u-N$-málá
$\rightarrow$ ku-m'-málá
'to make you/him sleep'
ku-N'-némá
$\rightarrow k u-n^{\prime}$-némá
ku-N'- nálá
$\rightarrow k u-n^{\prime}$-nálá
'to finish you/him'
'for you/him to not do correctly'
ku-N'- Đáándila

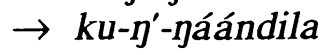
c. ku-N'-dípá
$k u-N^{\prime}$-déléla
$\rightarrow k u-n^{\prime}$-dípá
'to cut you/him into small pieces'
'to play around with you/him'
d. ku-N'-sóósá
$\rightarrow k u-n^{\prime}$-déléla
'to pay you/him'
'to understimate you/him'
$\rightarrow k u-n^{\prime}$-sóósá
'to look for you/him'

As in the case of the moraic nasal, the syllabic nasal is homorganic to the following consonant, almost the only effect that the two kinds of nasal prefixes share. Thus, as indicated in (12), the infinitive prefix $k u$ - does not undergo lengthening when followed by the syllabic nasal-versus the lengthening of $\mathrm{ku}$ that was seen before the moraic nasal in (7). In (12a) we see that voiceless consonants are not voiced after the syllabic nasal, nor do voiced consonants delete after the syllabic nasal in (12b). 9 The forms in (12c) show the same retention of [d] as was seen after the moraic nasal. Finally, (12d) shows that the syllabic nasal, unlike the moraic nasal, does not delete when followed by $/ \mathrm{s} /$.

Let us now consider the distribution of the syllabic nasal in Ciyao. We have already stated that there are no morpheme-internal syllabic nasals in the language. In (13) we see that it occurs in six prefixes: the three noun prefixes in (13a) and the three verb prefixes in (13b). The three noun class prefixes are illustrated in (14), (15), and (16). As in the case of the ' 2 nd/3rd person singular object prefix' in (12), a full range of consonants (voiceless, voiced) is found after the syllabic nasal noun class prefixes in (14)-(16).

9 The only consonant changes that take place after the syllabic nasal are seen in the second and third examples in (12b), where $/ v /$ and $/ 1 /$ become [b] and [n], respectively, after the syllabic nasal. 
(13) Syllabic nasal prefixes in Ciyao (no cases morpheme-internally)
a. N'- 'class 1 noun prefix'
$N^{\prime}$ - 'class 3 noun prefix'
$N^{\prime}-$ 'class 18 noun prefix'
b. $N$ ' - '2nd person subject prefix'
$N$ '- '2nd person object prefix
$N^{\prime}-$ '3rd person sg. object prefix'

(14) Noun class 1 prefix N'-

(plural formed with class 2 a-, e.g., a-palú 'hunters', etc.)
a. $m^{\prime}$-palú
n'-tágáluka
$n^{\prime}$-cíinga
$\eta^{\prime}$-kodi
'hunter'
'hare'
'herdsman'
'prisoner of war'
b. m'-bulusi
n'-núpáta
'foreigner'
$n^{\prime}$-jéénú
$\eta^{\prime}$-gadíba
'hunter'(pl. a-lúpáta)
m'-mágoongó
'your companion'
'master of initiation ceremony'
$n^{\prime}$-nami
j'-nééló
'enemy'
'liar'(pl. a-nami)
'glutton'
c. $n^{\prime}$-sonogo
'spouse'

(15) Noun class 3 prefix N'-

(plural formed with class 4 mi-, e.g. mi-piká 'borders' etc.)
a. m'-piká
'border'
$n^{\prime}$-téélá
'tree'
$n^{\prime}$-cígá
'root'
$\eta^{\prime}-k u ́ d i$
'honey badger'
b. m'-bále
'raphia palm'
n'-nékáasya
$n^{\prime}$-jiika
'prohibition' (pl. mi-lékáasya)
$\eta^{\prime}$-goóle
'waterlily'
m'-mweénya
'coconut palm'
$n^{\prime}$-neega
$n^{\prime}$-naalo
'rubiaceous tree (sp.)
n'-paándu
'swarm' (pl. mi-leega)
'bashfulness'
'Morning Star, Venus'
c. n'-dáala
'crack'
d. n'-sáku
'bag' 
(16) Noun class 18 locative prefix N'- 'in' (added outside the basic noun prefix, if any)
a. m'-péete
$n^{\prime}-t u-p u ́$
$n^{\prime}-c i-p i$
$\eta^{\prime}$-ka-diilole
'in the finger ring',
'in the little bones'
'in darkness'
'in the mirror'
b. m'-bóoma
$n^{\prime}$-nu-piinda
$n^{\prime}$-júuga
$\eta^{\prime}$-gólógolo
$m^{\prime}$-ma-luma
'in the government building'
'in the bag of salt' (lu-piinda)
'in the game of cards'
'in the weasel'
'in the joint'
n'-namandéléngwá
'in the thief'
c. n'-dy-oóla
'in the frog'

Compensatory lengthening, noted previously in (8) and (9) before the moraic nasal, does not occur before the syllabic nasal. For example, the final vowel of /leeló/ 'today' preceding the '2nd person singular subject prefix' in (17) does not lengthen, nor does the FV of ku-lék-á 'to leave' before the class 1,3 , and 18 syllabic nasal prefixes in (18).

(17) No lengthening of final vowel of preceding word before N''2nd person singular subject prefix'
leeló ńn'-tumíle
leeló ñ́'-capíile
a. leeló má'-peléece
leeló 'ñ'-kweesíle
'today you sent'
'today you ordered'
'today you washed for (s.o.)'
'today you climbed'
b. leeló m'-buucíle
leeló món-bacíile
leeló n'-napíle
leeló ñ́'-jiimíle
leeló 'ñ'-gonéece
leeló 'm'-masíle
'today you were angry'
'today you built for'
'today you admired'
'today you begrudged'
'today you made (s.o.) sleep'
leeló ńn'-nemíle
'today you finished'
leeló ñ'-nasíle
'today you did (sth.) incorrectly'
leeló n'n'-naandíile
'today you cut into small pieces'
'today you played around with (sth.)'
c. leeló n' n'-dipíle
leeló nn'-deléele
'today you paid'
'today you understimated'
d. leeló n'́n-soosíle 'today you looked for' 
(18) No lengthening of final vowel of preceding word caused by classes 1,3 , or $18 \mathrm{~N}^{\prime}$ - prefix
a. ku-léká mó'-palú
'to leave a hunter (cl.1)'
ku-léká n't-téélá
'to leave a tree (cl. 3)'
ku-léká $\quad n^{\prime \prime}-c i-p i$
'to leave in darkness (cl.18)'
ku-léká in'-kodi
'to leave a prisoner of war (cl.1)'
$\begin{array}{ll}\text { b. ku-léká } & \text { ná}^{\prime} \text {-bále } \\ \text { ku-léká } & n^{\prime} \text {-nu-piinda }\end{array}$
ku-léká jn'-jiika
ku-léká ñ'-goóle
'to leave a raphia palm (cl.3)'
ku-léká m'mámágoongó ‘
ku-léká $\quad n^{\prime}$-nami
'to leave in a bag of salt (cl.18)' (< lu-piinda)
'to leave a waterlily (cl.3)'
'to leave a coconut palm (cl.3)'
ku-léká ñ'-nééló
'to leave an enemy (cl. 1)'
'to leave a liar (cl.1)'
'to leave a glutton (cl.1)'
ku-léká 'n'-naándu
'to leave the Morning Star (cl. 3)'
c. ku-léká ñ'-sáku
'to leave a bag (cl.3)
d. ku-léká ñ'-dy-oóla 'to leave in a frog (cl. 18)'

As the tone-markings indicate, these phonetically syllabic nasal prefixes are also tone-bearing units and for this reason also require a mora in their underlying representation. If we compare the data from this section with the data in $\S 1$, however, it becomes immediately obvious that moraic-and-syllabic nasals are not only phonetically distinct from moraic nasals, but also have vastly different phonological properties. This then raises the question of how they should differ in representation. We have assumed in the preceding discussion that the moraic nasal has a representation such as that in (19a). If correct, this would mean that the syllabic nasal must be presyllabified, as in (19b). Since, as we shall see, the syllabic nasal derives from Proto-Bantu *mu-, these representations mirror the intuition we first held that the syllabic nasal is a syllable while the moraic one is not.
a. Moraic nasal $(\mathrm{N})$
b. Syllabic nasal $\left(\mathrm{N}^{\prime}\right)$

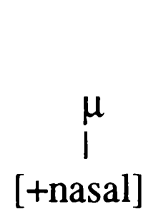

$\sigma$

$\mu$

[+nasal]

Under this approach, one could propose that the moraic nasal is free to have its effects (particularly lengthening of the preceding vowel) because it is not syllabified. The syllabic nasal, by contrast, being already rigidly prosodified, 
would be stable and non-interactive with the surrounding segments. This view is consistent with the notion that a syllabic element should be a syllable, as well as with the diachronic source of syllabic nasals in general. As is clear from such studies as Kadima [1969] and Bell [1972)] the moraic nasal existed already in Proto-Bantu, whereas syllabic nasals such as found in Ciyao derive from *musequences-which clearly constitute a syllable. 10 In the following section we shall see that the syllabic nasal, in fact, alternates with $m u$ - and $m w$ - in Ciyao. Despite this, we will argue for another interpretation of the two types of moraic nasals in this language, namely, that it is the syllabic nasal that has the representation in (19a), not the moraic nasal. We shall begin by demonstrating that a sequence of (C) $\mathrm{V}+$ syllabic nasal is one syllable not two-and that it is therefore not necessary to assume the presyllabification of $N^{\prime}-$.

\section{Against the presyllabification of $N^{\prime}$ -}

In this section we wish to argue for an analysis that does not stipulate the presyllabification of $\mathrm{N}^{\prime}$ - prefixes. The argument will center around a demonstration that $(\mathrm{C}) \mathrm{V}+\mathrm{N}^{\prime}$ sequences constitute one syllable rather than two.11 Evidence will be presented from three sources: vowel shortening, tonal decontouring, and allomorphy ( $\left.m u-/ m w-v s . N^{\prime}-\right)$.

3.1. Vowel shortening. The first argument is that vowels shorten before N'$\mathrm{C}$ sequences. The forms in (20) involve the same Past 2 "before today" past tense prefix -á- seen earlier in (10). The subject prefixes utilized are the moraic nasal $\mathrm{N}$ - '1st person singular', ju- 'third person singular' (class 1), tu- 'first person plural' and va- 'third person plural' (class 2). In (20a) we see that the first syllable in all cases involves a long [aa]. As shown in (21a), this length derives from the spreading of the -á- prefix onto the preceding moraic subject prefix (see (11) and note 2). Note, however, that before a syllabic nasal the vowel [á] is short, as in (20b). The question is why?

10 More rarely in other languages, particularly in the Northwest of the Bantu zone, they may derive also from *mi- and *ma-.

11 As far as we know, the question of whether a sequence of (C)V + syllabic consonant constitutes one vs. two syllables has not been addressed. In languages which do not have bimoraic syllables, the bisyllabic solution would seem to be imposed. Otherwise the answer may require close scrutiny on a language by language basis. What was striking to us in this study was that we initially assumed that the syllabic nasal constituted its own syllable - in fact as a lingering conservative feature of its former mu-shape. More striking to us now is how clear the arguments are against this assumption, at least for Ciyao. 
(20) Vowel shortening before $\mathrm{N}^{\prime}$
a. n-aa-péleéce 'I sent'
jw-aa-péleéce 'he sent'
tw-aa-péleéce 'we sent'
$v$-aa-péleéce 'they sent'
b. n-á-mó-peleéce 'I sent you/him'
$j w$-á-m'-peleéce 'he sent you/him'
tw-á-má'-peleéce 'we sent you/him'
$v$-á-m'-peleéce 'they sent you/him'

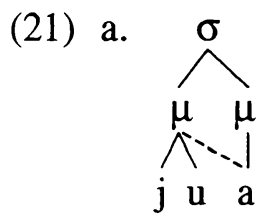
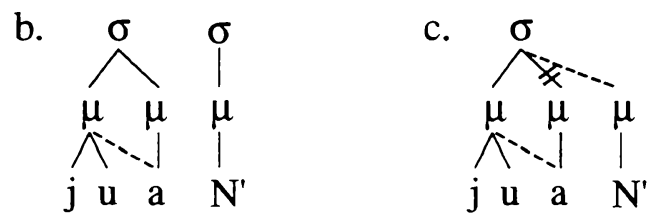

If we assume that the syllabic nasal is a separate syllable, as in (21b), we have no explanation. If, on the other hand, we assume that the syllabic nasal is moraic, but not syllabic, as in (21c), the explanation is at hand: As Clements [1986] demonstrated for Luganda, the syllable is maximally bimoraic in Ciyao. Thus, when the nasal joins the syllable in (21c), it is necessary that one of the other moras be delinked from the syllable node so as to avoid a trimoraic syllable. As indicated, and following Hyman and Katamba [1997], we assume it is the internal mora that is effaced in this way. 12 This then constitutes the first argument that $\mathrm{N}^{\prime}$ - joins a preceding $(\mathrm{C}) \mathrm{V}$ in the same syllable.

3.2. Tone decontouring. Additional arguments that $\mathrm{N}$ - functions the same as a $\mathrm{V}$ mora can be found in the tonal phonology of the language. Ciyao has two tones, $\mathrm{H}$ (igh) and $\mathrm{L}(\mathrm{ow})$, with a maximum of one tone per vowel. HL and $\mathrm{LH}$ contours are possible only under very restricted circumstances. One pervasive constraint is that a $\mathrm{H}$ tone may not begin on a $\mathrm{V}$ mora if the following (CV) mora is also $\mathrm{H}$. When such a sequence risks occurring, as in $(22 \mathrm{a}, \mathrm{b})$, the left branch of a doubly linked $\mathrm{H}$ is delinked. 13

12 Dealing with comparable phenomena, Hyman and Katamba [1997] propose that syllabification is edge-in in Luganda. In cases where three or more vocalic moras occur in sequence, e.g., in a CVVVV input string, the initial CV mora and the last $\mathrm{V}$ mora are syllabified, with all intervening moras being stray erased.

13 Hyman and Ngunga [1994] refer to the delinking in (22a) as contour simplification, while Odden refers to it as "no rise" [Odden, In press]. Since the initial CV mora in (22a) would receive a default $\mathrm{L}$ tone, delinking of the left branch of the $\mathrm{H}$ avoids a $\mathrm{CVV}$ syllable with a $\mathrm{LH}$ rising tone. If we assume an obligatorily present $\mathrm{L}$ tone, as in (22c), which links to the $\mathrm{V}$ mora (there labeled as $\mu_{\mathrm{W}}$, following Zec [1988]), then we can also view the process as one of linking (or spreading) of this $\mathrm{L}$ onto the $\mathrm{V}$ mora, thereby requiring by the one-tone-per-mora maximum that the $\mathrm{H}$ delink. 
(22) Left-branch H-delinking (restricted to VCV sequences)
a. C V V C V
b. $\mathrm{IP}\left[\mathrm{VCV}_{\mathrm{H}}^{\mathrm{V}}\right.$

As shown in (22), the $\mathrm{H}$ tone VCV sequence may either be preceded by a $\mathrm{CV}$ mora, as in (22a), or be initial in its intonational phrase (IP), as in (22b). The first situation is illustrated in the negative Past 2 "before today" tense forms in (23). The prefixes involved here are ngani- 'negative Past2' and -ju- ' $3 r d$ person singular' (class 1).

a. ngani-ju-divadil-a

ngani-ju-divadil-a

$\mathrm{n} / \mathrm{a}$ b. ngani-ju-piikan-a

$\mathrm{H}$
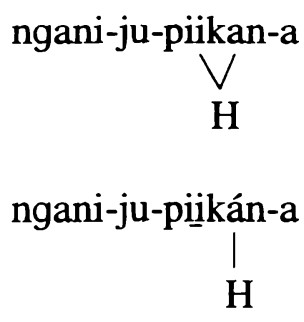

'he didn't forget'

\section{Input}

H tone spreading

\section{H delinking}

The input forms show the regular assignment of a morphological $\mathrm{H}$ tone to the second mora of the verb stem (= the verb minus any prefixes) in this tense. This is followed by a rule of $\mathrm{H}$ tone spreading (HTS) that spreads the $\mathrm{H}$ to the following mora. In (23a) the derivation stops there. In (23b), however, HTS produces the input to (22a) and the left branch of the $\mathrm{H}$ is delinked.

Now consider another tense where we can test the tonal behavior of the syllabic nasal. The Fut2 (general future) forms in (24) are marked by one prefix ci- preceding the subject prefix and another prefix -ci-following it. In this tense the only input $\mathrm{H}$ is the one prelinked with the subject prefix, here -jú- ' 3 rd person singular' (class 1), -á- '3rd person plural' (class 2), and - $\mathrm{N}$ '- '2nd person singular'. Again, the derivation begins with HTS. In (24a) nothing further happens. In (24b), the left branch of the doubly linked $\mathrm{H}$ is delinked as per (22a). Significantly, the same thing happens in (24c), where the left branch of the $\mathrm{H}$ is delinked from the syllabic nasal. This shows that $\mathrm{N}$ - has the same property as a $\mathrm{V}$ mora (and crucially does not behave like its CV- source *mu-). 
(24) Fut2 ci-...ci-

a. ci-ju-ci-lam-a

$\mathrm{H}$

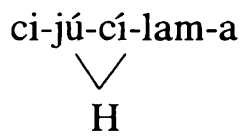

$\mathrm{n} / \mathrm{a}$ b. ci-a-ci-lam-a

$\mathrm{H}$

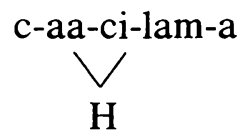

c-aa-cí-lam-a

$\mathrm{H}$ c. ci-N'-ci-lam-a Input

$\mathrm{H}$

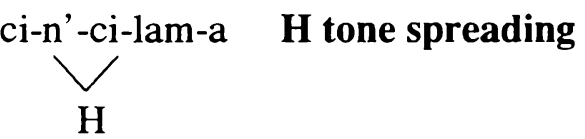

ci-n'-cí-lam-a $\quad \mathbf{H}$ delinking

'he will survive' 'they will ___ 'you will

The same conclusion can be drawn with respect to the related process in (22b). To illustrate this, consider the present tense forms in (25). In these forms, the infinitive prefix $-\mathrm{ku}$ - also marks the present tense. The underlying $\mathrm{H}$ tones appear on the subject prefix are jú-, á- and N'- as well as on the root -dí- 'eat', which is preceded by the class 7 object prefix -ci- 'it'.

(25) Present tense $-\mathrm{ku}$ -
a. ju-ku-ci-di-a
b. a-ku-ci-di-a
$\mathrm{H} \quad \mathrm{H}$
$\mathrm{H} \quad \mathrm{H}$
c. N'-ku-ci-di-a Input
$\mathrm{H} \quad \mathrm{H}$
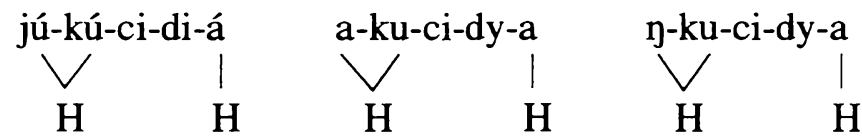

H tone spreading

$\mathrm{n} / \mathrm{a}$
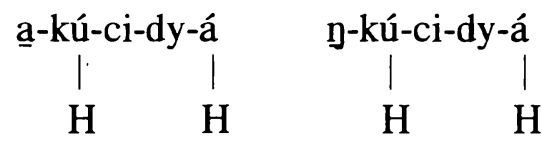

H delinking

'he is eating it'

'they are

'you are

After HTS applies, (25a) has a CVCV sequence with $\mathrm{H}$ tone and is wellformed. In (25b), however, the initial $\mathrm{H}$ sequence is $\mathrm{VCV}$ and $\mathrm{H}$ delinking must apply to the left branch of the $\mathrm{H}$. The same occurs in (25c), which has the structure $\mathrm{N}^{\prime} \mathrm{CV}$ and where the $\mathrm{H}$ delinks from the syllabic nasal.

The above are not the only cases where $\mathrm{N}^{\prime}$ - functions exactly as a V mora. Two additional tonal processes are presented in (26). Using Zec's [1988] labeled 
moras, where $\mu_{\mathrm{w}}=\mathrm{a} V$ mora, (26a) shows that when a $\mathrm{H}$ occurs solely to the $\mathrm{V}$ mora of a CVV syllable (i.e., is not doubly linked to the next CV mora), instead of delinking, it spreads onto the preceding head mora $\left(\mu_{\mathrm{S}}\right)$. In the example kú-úvá 'to hide (intr.)' in (26a), the FV -á is $\mathrm{H}$ tone, but its tone is from a second $\mathrm{H}$ feature (see [Hyman and Ngunga 1994]).

(26) When $\mathrm{H}$ is non-branching, disallowed contours are resolved by left- and right- HTS

a. $\mathrm{LH} \rightarrow \mathrm{HH}$

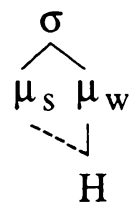

e.g.

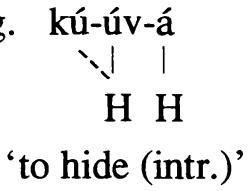

b. $\mathrm{HL} \rightarrow \mathrm{HH}$

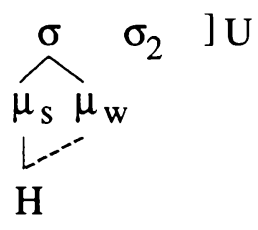

In the example in (26a), the rule of leftward HTS applies to what is clearly a CVV syllable. The question is what happens when we have a CVN' sequence with a single $\mathrm{H}$ on the syllabic nasal? We can test this in the Fut1 (near future) forms in (27). In this tense, a $\mathrm{H}$ tone tense prefix cí- precedes the toneless subject prefix tu- '1st person plural', which undergoes HTS. The FV is exceptionally -e (vs. the more frequent $-a)$.

(27) Realization of an underlyingly toneless noun prefix following verbs that place a $\mathrm{H}$ on next mora ['we will leave
a. cí-tú-lec-e cí-wuko cí-tú-lec-e mí-jiika a bag' waterlilies' $(<$ ci-wuko (cl. 7)) (<mi-jiika (cl.4))
b. cí-tú-lec-éé ந-goosa cí-tú-lec-éé nama a sheep' an animal'
$(<$ g-goosa (cl. 9))
(< n-nama (cl. 9))
c. cí-tú-lec-é á-palú cí-tú-lec-é á-nami hunters' [le.cáá] (< a-palú (cl. 2)) liars'
d. cí-tú-lec-é əm'-palú cí-tú-lec-é on'-jiika cí-tú-lec-é on'-ci-pi a hunter' *[le.ce m'] $\left(<m^{\prime}\right.$-palú (cl. 1)) *[le.ce ń'] (< n'-jiika (cl. 3)) a waterlily' in darkness' *[le.ce ń']
$\left(<n^{\prime}-c i-p i(\right.$ cl. 18))

As shown in (27a), this tense places a $\mathrm{H}$ tone on the prefix mora of the following noun, which in the two examples has the shape CV-. The forms in (27b) have class 9 object nouns, i.e., nouns with a moraic nasal prefix which in principle would receive the $H$ tone. Since the nasal leaves its mora as per the 
discussion in $\S 1$, the FV of the verb spreads to take its place and as a consequence is phonetically long. Since this mora derives from the noun prefix, it has a postverbal $\mathrm{H}$ tone. However, instead of deriving *ci-tú-lec-eé, the leftward HTS rule in (26a) converts the FV to -éé, i.e., with a $\mathrm{H}$ tone long vowel. The same happens in $(27 c)$ where there is a vowel sequence $-e+a-$. As seen to the right of the glosses, this sequence undergoes vowel coalescence and instead of a rising tone *-aá, (26a) again guarantees that -áá will be obtained. Finally, and most important to our demonstration, is the fact seen from the forms in (27d) that $\mathrm{N}^{\prime}$ behaves exactly the same way: Here we obtain a surface $\mathrm{H}$ tone on the FV -é as well as on the syllabic nasal! If N'- were its own syllable (like the CV-prefixes in (27a)), we would have expected the asterisked outputs to the right of the glosses in (27d). Again, N'- acts like any other V- mora.

The final tonal argument comes from the rule in (26b). As seen in (28a), a sequence HL-L is permitted if the falling tone is a penultimate CVV syllable. The $\mathrm{HL}$ is created by HTS. As seen in (28b), however, if the CVV is pre-penultimate, the HL created by HTS cannot surface as such. Instead, the rule in (26b) effects a second spreading such that one obtains a CVV with both moras $\mathrm{H}$.

(28) HL falling tone cannot be followed by two or more toneless syllables
a. ku-sévées-a 'to work'

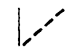
$\mathrm{H}$
b. ku-mányúídil-a
'to know'

c. tu-tum-11l-e 'we ordered'

$\mathrm{H}$

d. tu-tum-ill-é ci-tove 'we ordered a pixie'

$\mathrm{H}$

$\mathrm{H}$

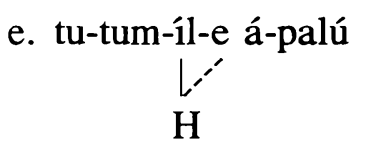

[..láá..]

f. tu-tum-íl-é mó'-palú

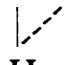

'we ordered hunters'

'we ordered a hunter'

The rule in (26b) allows us again to test whether a CVN' sequence will function the same as a CVV syllable or not. The input verb form to this test is given in (28c): the Pastl ("today past") tense places a $\mathrm{H}$ on the second mora of the verb stem, which is not allowed to spread to the FV at the end of a phrase. In (28d) it does spread to the FV -e, but does not affect the CV class 7 prefix ci-. In (28e) we have the sequence le+a which joins together to form a single [láa ] syllable. When HTS applies to the FV - e, it creates a HL syllable that is prepenultimate. As a result, (26b) must apply and convert this syllable to an all $\mathrm{H}$ [láá]. The form in (28f) is parallel except that the noun prefix is the syllabic nasal 
of class 1 . As shown, the output is the same as in (28e): HTS produces a [lém) sequence in prepenultimate position. If this were two syllables, it would not be clear why it could not surface as such. Since it obligatorily becomes [lému, we assume this is because a CVN' sequence is syllabified into a single syllable. For this reason its effect on both duration and tone is indistinguishable from a CVV syllable. Both are bimoraic syllables with the same properties.

3.3. Allomorphy. We have already alluded to the fact that the syllabic nasal prefixes of Ciyao are all derived historically from Proto-Bantu *mu-. The process of diachronic development, further exemplified by Kadima [1969] and Bell [1972] is shown in (29).

(29) Proto-Bantu

$$
*^{*} \text { mu-C }>\text { m'-C }>\mathrm{N}^{\prime}-\mathrm{C}
$$

First, the vowel $*_{\mathrm{u}}$ is lost, absorbed by labiality of the preceding $*_{\mathrm{m}}$, producing a syllabic $m$-. Then this syllabic $m^{\prime}$ - undergoes homorganic nasal assimilation.14 All six of the syllabic nasal prefixes listed in (13) derive from forms which Meeussen [1967] has reconstructed as *mu-.15 It does not come as a surprise, therefore, that $\mathrm{N}^{\prime}$ - alternates with $\mathrm{mu}$ - and $\mathrm{mw}$ - in Ciyao. Consider then the realization of the 2 nd person subject prefix in the imperative forms in (30).

14 The process of $*_{u}$ absorption is particularly favored by the presence of a following stem-initial labial consonant. Note that there are dialects of Ciyao which have syllabic $m-$, i.e., which have not yet subjected the syllabic bilabial nasal to homorganic nasal assimilation.

15 As indicated in (13) this includes three noun class prefixes $(1,3,18)$ and three verb prefixes: $m u$ - '2nd person plural subject prefix', -mu- '3rd person singular (class 1 ) object prefix', and -mu'2nd person plural object prefix'. There has been some semantic realignments, particularly involving 2nd vs. 3rd person and singular vs. plural (see Mbaga and Whiteley [1961]). Curiously, one additional prefix in Ciyao, the class 18 object prefix - $m u-$, also corresponding to Proto-Bantu ${ }^{*}$ mu-, may not become a syllabic nasal. As seen in the following forms, it must instead be realized as - $m u$-:

Class 18 -mu- object prefix 'in (it)' does not become $-\mathrm{N}$ '-:

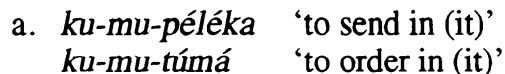
ku-mu-cápíla
'to wash for in (it)'
ku-mu-kwééla
'to climb on in (it)'
ku-mu-lápá 'to admire in (it)'
ku-mu-jǘmá 'to begrudge in (it)'
ku-mu-gónéka 'to make in (it) sleep'
b. ku-mu-búúcila 'to be angry with in (it)'
ku-mu-málá
ku-mu-némá
ku-mu-nálá
ku-mu-náándila
'to finish in (it)'
'for in (it) to not do correctly'
'to cut in (it) into small pieces'
'to play around with in (it)'
c. ku-mu-dipá 'to pay in (it)'
ku-mu-déléla
'to understimate in (it)'
d. ku-mu-sóósá 'to look for in (it)' 
(30) $\mathrm{N}^{\prime}-\mathrm{m} \mathrm{m}-\mathrm{mu}$ - alternations in Ciyao

(2nd person subject prefix in imperative)
a. N'-túme
$\rightarrow$ n'-túme
'order!'
b. mú-á-túme $\rightarrow$ mw-áá-túme 'order them!' (-a- 'class 2 object prefix')
c. mú-Ń-túme $\rightarrow$ múú-n-dúme 'order me!'(-Ń- '1 pers. sg. obj. prefix')
d. mú-N'-túme $\rightarrow$ mú-ñ'-túme 'order him!'(-N'- '3 pers. sg. obj. prefix')

When followed by a consonant-here stem-initial $/ \mathrm{t} /$ - the form of the 2nd person subject prefix is the syllabic nasal seen in (30a). 16 When followed by a vowel such as the 3rd person plural prefix (class 2) -a- in (30b), the output is [mwáá], suggesting an input /mú-á-/. In (30c), the 2nd person subject prefix is followed by the moraic nasal of the 1 st person singular object prefix. As shown, the output is [múú] followed by a prenasalized consonant, suggesting the input /mú-N-/. Finally, in (30d), the 2nd person subject prefix is followed by the syllabic nasal of the 3rd person singular object prefix. As indicated, the phonetic realization [mú-ń'] suggests an input /mú-N'-/.

From the examples in (33), it appears that a syllabic nasal will occur only if the morpheme in question is directly followed by a consonant (other than a moraic or syllabic nasal). The same alternations can be observed in the corresponding noun class prefixes. The forms in (31), (32), and (33) show the realization of class 1,3 , and 18 noun class prefixes when followed, respectively, by a vowel, a moraic nasal, and a syllabic nasal. The results are the same as in the imperative: In (31) we obtain [mw-] followed by a long vowel. In (32) we obtain [muu] followed by a prenasalized consonant. Finally, in (33) the class 18 prefix (which alone among the three can be followed by another noun class prefix) is realized [mu-] followed by a syllabic nasal.

(31) Realization of class 1,3 , and 18 noun prefixes as $m w$ - before a vowel
a. $m w$-iípwa
mw-eénye
'son or daughter'
(class 1)
mw-aanáce
'master'
mW-aadimú
'child'
'teacher'

16 In this tense the subject prefix carries a $\mathrm{H}$ tone, which also spreads to the next vowel. In (30a) the left-branch $\mathrm{H}$-delinking rule has removed the $\mathrm{H}$ from the subject prefix itself. 

b. mw-aanda
mw-aango
'great number'
'elephant's trunk'
(class 3)
mw-iimbila
'burrow'
mw-iisámuló
'sneeze'
c. mw-ii-gaasa
'handful'
mw-ii-tála
'in the path'
mw-aa-leendo
'in the guests'
mw-aa-sávi
'in the wizards'
(class 18)

(32) Realization of class 1,3 , and 18 noun prefixes as $m u$ - before moraic $\mathrm{N}$ (which causes length)
a. muu-ndu
'person'
(class 1)
b. muu-n-dálaanga muu-n-jala
muu-n-gwe
'kind of dance'
'abaceous tree (sp.)'
(class 3)
'plant-bearing fruit'
c. muu-m-búsí 'in a goat'
muu-meémbe17 'in a fly'
muu-n-dinú
muu-sóomba
'in a porcupine'
'in a fish'

(33) Realization of locative class 18 noun prefix as $\mathrm{mu}$ - before syllabic N'(with no length)
a. $m u-m^{\prime}-$ palú
$m u-n^{\prime}-c i ́ i n g a$
$m u-n^{\prime}-n a m i$
$m u-n^{\prime}$-sonogo
'in a hunter'
'in a herdsman'
'in a liar'
'in a spouse'
b. $m u-m^{\prime}$-piká
'in a border'
'in a coconut palm'
(class 18+3)
mu- $\eta^{\prime}$-goóle
$m u-n^{\prime}-s a ́ k u$
'in a bag'
mu-n'-téélá
'in a tree'
c. $m u-m^{\prime}$-péete
$m u-n^{\prime}-t u l u ́ p u$
mu-m'-báasi
mu- $\eta^{\prime}-k a a ́ t a$
'in a finger-ring'
'in a card game'
'in a bus'
'in a calabash cup'
(class 18+1)
(class 18+18)

17 These last two forms are from mu-m-meémbe and mu-n-sóomba, respectively. 
How should these alternations be accounted for? What we have labeled a "standard derivational account" is presented in (34). Mirroring the historical events, (34a) first deletes the [u] of $m u$ - prefixes when followed by a consonant. 18 Homorganic nasal assimilation then applies as in (34b), spreading the place of articulation of a consonant onto the preceding nasal.

(34) Standard derivational account

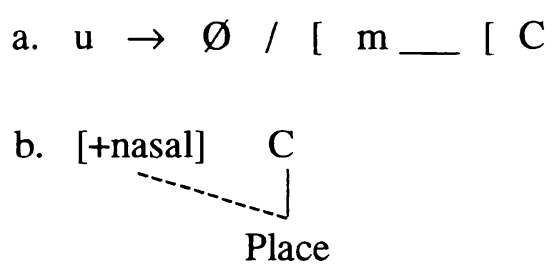

For this account to work, however, it is necessary that the " $\mathrm{C}$ " in (34a) not include either the moraic nasal or the syllabic nasal itself (both of which are presumably [+cons]). One might think of invoking some form of the obligatory contour principle (OCP) to block the development of a syllabic nasal before a nasal. Note first that the syllabic nasal is derived before a non-moraic nasal (see the examples in (12b), (14b), (15b), (16b), etc.). Worse yet, as we shall now show, a syllabic nasal can also be derived before an underlying prenasalized consonant, the third source of preconsonantal nasal referred to above in (1c).

As shown in (35), unlike Proto-Bantu, Ciyao has a certain number of verb roots that begin with a prenasalized consonant. This preconsonantal nasality does not cause lengthening of a preceding vowel, i.e., the infinitive prefix $\mathrm{ku}$ - has a short vowel in these forms. It therefore cannot be equated with the moraic nasal. Nor can it be identified with the syllabic nasal, from which it is phonetically distinct (shorter, non-syllabic).

(35) Underlying prenasalized consonants:

no vowel lengthening before NC-initial verbs

$\begin{array}{ll}\text { ku-ndúúndumila } & \text { 'to shiver, as with cold' } \\ \text { ku-njóónjoka } & \text { 'to hop like a bird' } \\ \text { ku-ngúúmbá } & \text { 'to deceive' } \\ \text { ku-ngálágandula } & \text { 'to startle' }\end{array}$

18 It is clear that only prefixes are involved here. First, [mu] stem syllables do not become [m']. Thus, lu-mudi 'torch (in general)' and n-dumu 'earthenware (or china) cup (no handle)' may not become $1 u-n^{\prime} d i$ or $n$-dum'. Also, the class 18 enclitic $=m u ́$ may not become $=m^{\prime}: m u-m-p i k=m u ́$ 'in this border' (*mu-m-pikáá =m'). 
We must therefore set up a third type of preconsonantal nasality: a single underlying consonant within which a change from [+nasal] to [-nasal] is effected. The rule of HTS seen earlier and again exemplified in (36) provides tonal evidence that this is the right analysis.

(36) $\mathrm{N}$ in verbs with exceptional non-lengthening of V's before internal $\mathrm{NC} \neq \mathrm{a} \mathrm{TBU}$
a. ku-téléka
ku-divádila
'to cook'
'to forget'
b. ku-táámila
ku-sáádila
'to sit on'
'to inform'
c. ku-lóóndela
ku-páándila
'to target at'
'to sow for'

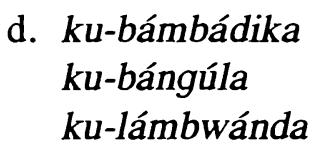
ku-mángála
'to bolt one's food'
'to roar'
'to boil'
'report a case at law'

In these verb forms there is an input $\mathrm{H}$ tone on the first mora of the verb stem which, by the regular rule of HTS, spreads onto the next mora. In (36a), where the first stem syllable is $\mathrm{CV}$, the $\mathrm{H}$ spreads onto the vowel of the second syllable. In (36b), where the first stem syllable is CVV, the $\mathrm{H}$ spreads onto the second $\mathrm{V}$ of this syllable. In (36c), where a moraic nasal has lengthened the $\mathrm{V}$ of the first syllable, again HTS spreads the $\mathrm{H}$ onto the second mora of the initial syllable. The crucial test examples are those in (36d), which begin with a CVNCV string, i.e., where the first stem vowel is followed by a NC but is nonetheless short. As seen, HTS spreads the $\mathrm{H}$ in this case onto the next syllable. We thus safely conclude both from the length and tone facts that this third type of preconsonantal nasality should be analyzed as an underlying prenasalized consonant.

Now consider the realization of the syllabic nasal prefixes before an underlying prenasalized consonant. In (37a) we note that the vowel of $t u$ - ' 1 st person plural subject prefix' is realized short. This is consistent with our analysis of these NC initials as prenasalized consonants (which have no mora to which the preceding vowel can spread). Also consistent are the facts in (37b). Here we see that stems beginning with a prenasalized consonant take the syllabic nasal variant-rather than the mu- variant-of the 2nd person subject marker. 
(37) 2nd pers. subj. prefix N'- used before NC-initial verbs
a. tu-ndúúndumil
tu-njóónjoce
'let's shiver!'
tu-jjóónjoce
tu-クgúumbe
'let's hop like a bird!'
tu-நgálagandule
'let's deceive!'
'let's startle!'
b. n'-ndúúndumile 'shiver!'
$n^{\prime}$-njóónjoce
'hop like a bird!'
$\eta$ '-ᄁgúumbe
'deceive!'
n'-ngálagandule
'startle!'

The same phenomenon is observed in (38) with respect to the ' $2 \mathrm{nd} / 3 \mathrm{rd}$ person object prefix'.19 In (38a), the ' 1 st person plural object prefix' -tu- is realized short, and in ( $38 \mathrm{~b})$, the ' $2 \mathrm{nd} / 3 \mathrm{rd}$ person object prefix' is realized as $\mathrm{N}$ ', not as mu-.

(38) $2 \mathrm{nd} / 3$ rd object prefix $\mathrm{N}^{\prime}$ is also used before NC-initial verbs
a. ku-tu-ngúúmb-il-a
'to deceive for us'
ku-tu-njóónjoc-el-a
'to hop like a bird for us'
b. $k u-\eta^{\prime}-$ ggúúmb-il-a
ku-n'-njóónjoc-el-a
'to deceive for you/him'
'to hop like a bird for you/him'

Finally, note in (39) that the same facts are to be found in nouns as well. In (39a) we see that there are nouns beginning with a short CV prefix followed by a stem-initial prenasalized consonant. In (39b) and (39c), we see examples of class 1 and class 3 nouns, respectively, which begin with a prenasalized consonant and, hence, take the $\mathrm{N}^{\prime}$ - prefix variant (not $\mathrm{mu}$-). 20

Given these data, it is clear that the use of $/ \mathrm{mu}-/$ before both the moraic and the syllabic nasals cannot be due to an OCP effect. Instead, we suggest an analysis in terms of allomorphy that, in fact, supports our view that $\mathrm{N}^{\prime}$ - should not be analyzed as prelinked to its own syllable node. The generalization that emerges from the facts of this subsection is given in (40).

19 In these forms we have added the applicative suffix -il-/-el- 'for' (benefactive).

20 Finally, we note that when a moraic nasal is followed by a prenasalized consonant, the moraic nasal simply drops out, potentially lengthening a preceding vowel, e.g., ku-N-ngúúmb-il-a $\rightarrow$ kuu-ngúúmb-il-a 'to deceive for me' (vs. ku-ngúúmb-il-a 'to deceive for'). 
(39) N'+prenasalized consonant also found in classes 1 and 3 SINGULAR
a. di-ndaanda ci-ndóolo 'egg'
b. $n^{\prime}-n j u s i$ 'beggar'
c. n'-ndógoodya
$n^{\prime}$-ndíimu
'climbing shrub (sp.)'
'lemon tree'
$\eta^{\prime}$-nguunga
'euphorbiaceous tree (sp.)'

PLURAL

ma-ndaanda
yi-ndóolo

a-njusi

mi-ndógoodya

mi-ndíimu
CLASSES

$5 / 6$

$7 / 8$

$1 / 2$

$3 / 4$

$3 / 4$

$3 / 4$

(40) Generalization: N'- appears only as last mora of its syllable

a.

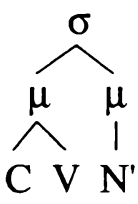

b.

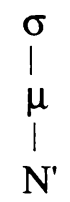

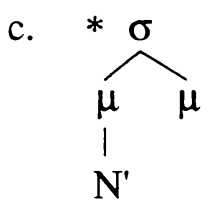

Given the limitations on Ciyao syllable structure, there are logically three places where a syllabic nasal could be found. Two of these are realized: In (40a) we see the $N^{\prime}$ may appear as the second mora of a bimoraic syllable. In (40b) we see the $N^{\prime}$ can appear as the sole mora of a monomoraic syllable. Where it cannot appear, as indicated in (40c), is as the first mora of a bimoraic syllable. In other words, rather than deriving $\mathrm{N}^{\prime}$ from $/ \mathrm{mu}-/$ phonologically, it is possible to introduce a statement of allomorphy, as given in (41). In (41a) we see that the relevant prefixes are spelled out as mu- if they can be syllabified as the first mora of a bimoraic syllable. In (41b) we treat $\mathrm{N}^{\prime}$ - as the elsewhere case, i.e., appearing if either the second mora of a bimoraic syllable or as the sole mora of a monomoraic syllable. 21

(41) Allomorphy statement of $\mathrm{N}^{\prime}-/ m u$ - prefixes

a. prefix $\rightarrow m u$ - if occurring as the first mora of a bimoraic syllable

b. prefix $\rightarrow$ N'- elsewhere

It should be clear that a statement such as (41) would be possible only if we recognized a CVN' sequence as one syllable, as in (40a). If the syllabic nasal were its own syllable, we would be especially hard put to explain why we cannot get

21 It would, of course, be possible to reformulate the statement so that N'- is spelled out "as the final mora of a syllable", with $\mathrm{mu}$ - being the elsewhere case. We prefer the first solution since we believe that $\mathrm{N}^{\prime}$ is the general case-and may even some day replace $m u$-in some or all of the environments in which it now occurs. 
more than one syllabic nasal in a row, i.e. why (30d) is not realized *ńn'-ń'-túme 'order him!' The allomorphy we have proposed is in fact an instantiation of Hyman and Katamba's [1997] "Avoid $\sigma$ [ VV" in Luganda.22 As support for this view, we cite in (42) additional evidence that Ciyao uses allomorphy to avoid VV syllables. The forms in (42a) show that the class 2 noun prefix (Proto-Bantu *ba-) is realized a- when followed by a consonant. In (42b), however, we see that its form is va- when followed by a vowel (with which it coalesences). The one example in (42c) shows the allomorph va- when followed by the moraic nasal of the stem -ndu 'person, people'. Here, as with $\mathrm{N}^{\prime}$-, it is clear that the CVallomorph is the historical form and that the non-branching mora variant is the innovation. The reason for not extending it to the forms in (42b) is that VV syllables would result. The same would be true in (42c), where an input */a-ndu/ would surface as [aandu], i.e., with an initial VV syllable. 23

(42) a-/va- allomorphy in class 2 noun prefixes
a. a-cíinga
'herdsman'
(sg. n'-)
a-tágáluka
'cross-cousins'
(sg. n'-)
a-culúúsi
'hare'
(sg. n'-)
(sg. n'-)
b. vá-áná
$v$-eénye
$v$-eéno
'peddlar'
(sg. mw-ááná)
(sg. mw-eénye)
'children'
'masters'
'fellow'
(sg. mw-iíno)
c. vaa-ndu
'people'
(sg. muu-ndu)

We thus conclude not only that $\mathrm{N}^{\prime}$ - does not constitute its own syllable, but that its distribution is determined by its position in the syllable (which it shares with a preceding CV mora).

22 This extension of Itô's [1989] onset condition has figured in various presentations on the Luganda syllable since 1993, now Hyman and Katamba [1997]. Bantu languages such as Luganda and Ciyao thereby attempt to avoid VV syllables, which violate both the onset principle as well as have complex (bimoraic) structure. It is natural then that VV would rank lowest among the few syllable types available in these languages.

23 This va-/a- allomorphy characterizes all class 2 concords within the noun phrase, e.g., on possessives, demonstratives, etc. The class 2 subject prefix, on the other hand, shows a slightly different allomorphy. A comparison of the forms in (a) and (b) will reveal that the class 2 subject prefix is realized va- before a vowel, but is realized a- not only before before a consonant but also before a moraic nasal or a syllabic nasal.
(a) P1 (today) past tense
(b)
a-tumíle
a-n-dúmíle
a-n'-túmíle
P2 (before today) past tense
$v$-aa-túmilé
$v$-áá-n-dumilé
$v$-á-ñ'-tumilé
'they sent'
'they sent me'
'they sent him/you' 


\section{Conclusion}

In the preceding sections we have surveyed the properties of three types of preconsonantal nasality: the moraic nasal, the syllabic nasal, and a third type of preconsonantal nasality whose representation was said to be that of an underlying prenasalized consonant. While the distinction in representation of the two moraic nasals was said to be the presence vs. absence of a prelinked syllable node in (19), in $\S 3$ we failed to establish any evidence for underlying syllable structure in the case of the syllabic nasal. Evidence from vowel length, tone and allomorphy led to the inescapable conclusion that CVN' sequences syllabify as a single syllable. Given the current fashion in phonology to minimize structure-changing derivations and the principle of "lexicon optimization" [Prince and Smolensky 1993], we propose to streamline the earlier representations of (19) into those in (43).

(43) Representations with projected-unlinked vs. projected-linked moraic nasals (cf. Zec [1992])

a. Moraic nasal $(\mathrm{N}) \quad$ b. Syllabic nasal $\left(\mathrm{N}^{\prime}\right)$

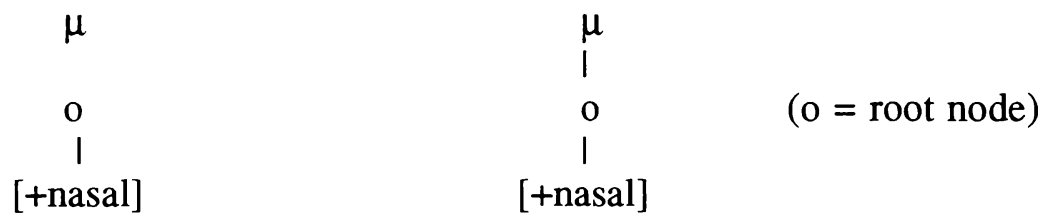

As implied in the title of this paper, there are indeed two kinds of moraic nasal-and neither one of them need constitute a syllable on its own. Using Zec's [1992] notion of mora projection, we can say in (43a) that the moraic nasal has a projected, but unlinked mora vs. the moraic-and-syllabic nasal in (43b), which has a projected and linked mora. One consequence of having the moraic nasal unlinked in (43a) is that the question raised in $\S 1$ of whether to interpret compensatory lengthening as resulting from a "push" or "pull", as illustrated in (5), now disappears.

To the representations in (43), we need only add in the spirit of optimality theory [Prince and Smolensky 1993] a hierarchy of constraints such as in (44).

(44) Preserve Moraic Links >> Avoid Moraic Nasals >> Avoid Prenasalized Consonants

The fate of $(43 a, b)$ will be determined in part by these ranked constraints: (43a) will involve the linking of the [+nasal] root node to the following mora, since avoiding moraic nasals is higher ranked than avoiding prenasalized consonants. When followed by a consonant, (43b), on the other hand, will remain a moraic 
nasal (rather than creating a prenasalized consonant) because preserving underlying moraic links is ranked higher than avoiding moraic nasals. The choice of the mu- allomorph over $\mathrm{N}^{\prime}$ - is in turn a case of phonologically conditioned allomorphy. As indicated above, it is motivated by the desire to avoid VV syllables, ranked high in Ciyao. 24

While we are quite pleased with our result, it is perhaps useful to keep an open skeptical mind. Thus, in the interest of completeness, we offer the following concerns that we still have about the argumentation that we have presented in favor of CVN' as one syllable.

First, concerning the argument made on the basis of vowel shortening, we note that some languages have vowel-shortening rules in a strictly vocalic context. Thus, as indicated in (45a), Gokana shortens a long vowel which immediately follows another vowel, while in (45b), Kikamba shortens a vowel that immediately precedes another vowel. There is no need in such cases to invoke the syllable. We have done so in analyzing CVN' sequences because the postulation of a single CVN' syllable greatly simplified the analysis-that is, because a general account was obtained that could be related to other phenomena within and beyond Ciyao (specifically to the maximal bimoraic condition on syllables).

(45) Some languages have vowel-shortening in a vocalic context
a. VV $\rightarrow$
$\mathrm{V} / \mathrm{V}$
(Gokana; [Hyman 1985])
b. $\mathrm{VV} \rightarrow \mathrm{V} /[-\mathrm{V}$
(Kikamba; [Roberts-Kohno 1995])

The second concern we have is that some Bantu languages appear to have $m u$ /N'- allomorphy without having bimoraic syllables [Ngonyani 1993; Kadima 1969; Bell 1972] - but requires further attention. Since in these languages there is no V/VV opposition, and hence no bimoraic maximality, it would be difficult to formulate an argument that a CVN' sequence is one syllable. In order to be totally convinced of our argumentation, then, we would need to look more in

24 Since our goal in this paper has been primarily to establish the contrasting types of preconsonantal nasality, we will not purpose other possible representations or implementations of OT here. We do note, returning to the derivation in (34), that a judicious use of underspecification might lead to the postulation of a single underlying representation for $m u$ - $/ \mathrm{N}^{\prime}$ - prefixes such as following:

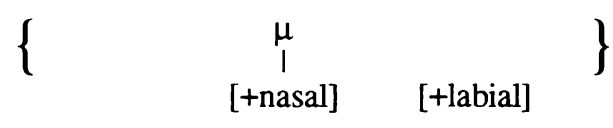

Perhaps by establishing additional constraints such as Homorganic Nasal Assimilation $>>$ Link [+labial] we could make the analysis seem more phonological and less allomorphic. Our initial attempts have however not led to any substantial improvement in the conceptualization or understanding of the phenomena under investigation. 
detail as such languages to be sure that they do not require the same kind of analysis as in Ciyao.

These two reservations aside, the case for two types of moraic nasal in Ciyao is respectfully submitted.

\section{REFERENCES}

Bell, Alan. 1972. "The development of syllabic nasals in the Bantu noun class prefixes $m u-$, mi- and ma-." Anthropological Linguistics 14:29-45.

Bickmore, Lee. 1989. Kinyambo Prosody. Ph.D. dissertation, University of California, Los Angeles.

Bickmore, Lee. 1991. "Compensatory lengthening in Kinyambo." In Francis Katamba (ed.), Lacustrine Bantu phonology, Afrikanistische Arbeitspapiere 25:75-103. Institut für Afrikanistik, University of Cologne.

Cheng, Chin-Chuan and Charles W. Kisseberth. 1982. "Tone-bearing nasals in Makua." Studies in the Linguistic Sciences 12:123-139.

Clements, George N. 1986. "Compensatory lengthening and consonant gemination in Luganda." In L. Wetzel and E. Sezer (eds.), Studies in Compensatory Lengthening, pp. 37-78. Dordrecht: Foris.

Clements, George N. and Samuel Jay Keyser. 1983. CV phonology. Cambridge, MA: M.I.T. Press.

Downing, Laura Jo. 1991. "The moraic representation of nasal-consonant clusters in Jita." In Francis Katamba (ed.), Lacustrine Bantu phonology. Afrikanistische Arbeitspapiere 25:105-130. Institut für Afrikanistik, University of Cologne.

Givón, Talmy. 1974. "Rule un-ordering: generalization and de-generalization in phonology." In A. Bruck, R.A. Fox, and M. LaGaly (eds.), Papers from the Parasession on Natural Phonology, pp. 103-115. Chicago: Chicago Linguistic Society.

Guthrie, Malcolm. 1967-1971. Comparative Bantu, Vols. 1-4. Farnborough, Hants: Gregg Press. 
Harries, Lyndon. 1950. A Grammar of Mwera. Johannesburg: University of Witwatersrand Press.

Hayes, Bruce. 1989. "Compensatory lengthening in moraic phonology." Linguistic Inquiry 20:253-306.

Herbert, Robert K. 1986. Language Universals, Markedness Theory, and Natural Phonetic Processes. Berlin: Mouton de Gruyter.

Hubbard, Kathleen A. 1994. "Duration in moraic theory." Ph.D. dissertation, University of California, Berkeley.

Hubbard, Kathleen A. 1995. "Morification and syllabification in Bantu languages." Journal of African Languages and Linguistics 16:137-155.

Hubbard, Kathleen A. 1996. “Prenasalized consonants and syllable timing: evidence from Runyambo and Luganda." Phonology 12:235-256.

Hyman, Larry M. 1985. A Theory of Phonological Weight. Dordrecht: Foris.

Hyman, Larry M. 1992. “Moraic Mismatches in Bantu.” Phonology 9:255-265.

Hyman, Larry M. and Francis X. Katamba. 1997. "The syllable in Luganda phonology and morphology." Submitted to Harry van der Hulst and Nancy Ritter (eds.), The Syllable: Views and Facts. Proceedings of the Conference on the Syllable in the Languages of the World. June 21-24, 1996. Pézénas, France.

Hyman, Larry M. and Armindo Ngunga. 1994. "On the non-universality of tonal association 'conventions': Evidence from Ciyao.” Phonology 11:25-68.

Itô, Junko. 1989. "A prosodic theory of epenthesis." Natural Language and Linguistic Theory 7:217-259.

Kadima, Marcel.1969. "Le système des classes en bantou." Ph.D. dissertation, Catholic University of Leuven, Belgium.

Kenstowicz, Michael and Charles Kisseberth. 1977. Topics in Phonological Theory. New York: Academic Press.

Maddieson, Ian. 1993. "Splitting the mora." UCLA Working Papers in Phonetics 83:9-18. 
Mbaga, K., and W.H. Whiteley. 1961. "Formality and informality in Yao speech." Africa 31:135-146.

Meeussen, A.E. 1967. Bantu Grammatical Reconstructions. Tervuren: Annales du Musée Royal de l'Afrique Centrale. Série 8, Sciences Humaines. No. 61:81121.

Mtenje, Al. 1990. "Verb Morphology and Tone Assignment in Ciyao." Afrikanistische Arbeitspapiere 28:41-59.

Ngonyani, Deo. 1993. "Nasality and syllable structure in Kindendeule." Ms. University of California, Los Angeles.

Ngunga, Armindo. 1995. "Phonological vs. phonetic vowel length in Ciyao." Paper presented at the Annual Meeting of the Linguistics Society of America, New Orleans.

Odden, David. In press. "Principles of tone in Tanzanian Yao." In Larry M. Hyman and Charles Kisseberth (eds.), Theoretical Aspects of Bantu Tone.

Odden, David. 1991. "VVNC in Kimatuumbi and Kikongo." South African Journal of African Languages 10:159-165.

Odden, David. 1994. "The Origin of Leftward Tone Shift in Masasi Chiyao." Berkeley Linguistics Society 20, Special Session on Historical Issues in African Linguistics. Pp. 101-111.

Odden, David. 1996. The Phonology and Morphology of Kimatuumbi. Oxford: Clarendon Press.

Prince, A. and P. Smolensky. 1993. "Optimality theory: constraint interaction in generative grammar." Ms. Rutgers University and University of Colorado.

Roberts-Kohno, R. Ruth. 1995. "Empty root nodes in Kikamba: conflicting evidence and theoretical implications." Paper presented at 26th Annual Conference on African Linguistics, University of California, Los Angeles.

Shaw, Patrica A. 1993. "Templatic evidence for the syllable nucleus." In Amy J. Shafer (ed.), Proceedings of the North East Linguistics Society 23, pp. 463477. Amherst: GLSA.

Steriade, Donca. 1991. "Moras and other slots." Formal Linguistics Society of Midamerica 1:254-280. 
Tucker. A. N. 1962. "The syllable in Luganda: a prosodic account." Journal of African Languages 1:122-166.

Zec, Draga. 1988. "Sonority constraints on prosodic structure." Ph.D. dissertation, Stanford University.

Zec, Draga. 1992. "Coda conditions and conditions on syllable weight." Ms. Cornell University.

Department of Linguistics

University of California

Berkeley, CA 94720

hyman@socrates.berkeley.edu

asangu@uclink.berkeley.edu
[Received June, 1997; accepted August, 1997] 
